\title{
The Antimicrobial Activity of Carissa carandas L., Ficus carica L., and Olea europaeae L. Leaves Extracts on Growth of some Pathogenic Microorganisms
}

\author{
May H. Shafeeq ${ }^{*}$, Lina A. Omar-Zahid* and Ban A. J. Sidkey ${ }^{* *}$ \\ * Department of Biology, College of Science, University of Baghdad, Baghdad-Iraq. \\ ${ }^{* *}$ Central Environmental Laboratory, College of Science, University of Baghdad, Baghdad-Iraq.
}

\begin{abstract}
Plant extracts were approved to heal many diseases, so three medicinal plants namely Carissa carandas L., Ficus carica L. and Olea europaeae L. were collected from different regions of Baghdad, in which their ethanolic crude extracts of leaves were assayed for antimicrobial activity against various pathogenic microorganisms such as: Gram-negative bacteria (Escherisha coli, Pseudomonas aeruginosa), Gram-positive bacteria (Staphylococcus aureus, Bacillus subtilis), yeast (Saccharomyces cerevisiae) and fungi (Penicillium species). Antimicrobial activity was conducted by the agar well diffusion method. The plant leaves extracts showed various levels of antimicrobial activity on different test microorganism, Gram negative bacteria, S. aureus and yeast were sensitive to the leaves extracts of the three plants, while B. subtilis and the fungus showed a moderate sensitivity against the leaves extracts of the three plants. The crude leaves extract of Ficus carica L. showed higher effect than the other two plants against pathogenic microorganisms.
\end{abstract}

Keywords: Carissa carandas L., Ficus carica L., Olea europaeae L.

\section{Introduction}

Multidrug resistance is a growing problem in the health care units nowadays, because of the increasing rates of the bacteria that are able to be transformed in association with the antibiotic administration in many cases [1]. The multidrug resistance in microorganisms led to the development of drug section and the usage of complicated types of antibiotics which are mostly toxic and have major side effects that can cause many damages inside the human body or gaining more weight with prolonged administration $[\Upsilon, r]$.

According to these serious issues and the increased needs to overcome such difficulties, the attention of the scientist was drawn to an ancient concept which is the activity of medical plants, herbs and natural products that can assist in finding solutions $[\varepsilon, 0]$. Plants are rich in a wide variety of secondary metabolites, such as tannins, terpenoids, alkaloids, and flavonoids, which have been found in vitro to have antimicrobial properties. Since many of these compounds are currently available as unregulated botanical preparations and their use by the public is increasing rapidly, clinicians need to consider the consequences of patients self-medicating with these preparations [\urcorner$, \vee]$.
Carissa carandas L. is a species of flowering shrubs in the dogbane family, Apocynaceae. It produces berry-sized fruits that are commonly used as a condiment in Indian pickles and spices. The fruit is a rich source of iron, so it sometimes used in treatment of anemia. It contains a fair amount of vitamin $\mathrm{C}$ and therefore is an antiscorbutic. Mature fruit contains pectin and accordingly is a useful ingredient in jelly, jam, syrup and chutney. Only a few reports are available for the antimicrobial properties of this plant $[\wedge, 9]$.

Ficus carica $\mathrm{L}$. is a species of flowering plant in the genus Ficus, from the family Moraceae, known as the common fig, leaves are rich in phenols, essential oils, flavonides and other bioactive compounds such as arabinose, $\beta$-amyrins, $\beta$-carotenes, glycosides, $\beta$-setosterols and xanthotoxol, its high content of alkaloids, glycosides and flavonides made it an active pharmacological agent $[1 \cdot, 11,1 \mathrm{r}]$.

Olea europaeae L. is an evergreen tree or shrub. The antimicrobial activity of a plant is highly related to secondary substances that are synthesized and produced by these plants. Secondary metabolites are substances of low molecular weight, which are not products of the primary metabolic pathway of the producing organism and at first thought to be 
with no advantage to the plant [ $1 \mathrm{~T}]$. Nowadays it is believed that they have vital functions. They may act as messenger molecules under specific circumstances (e.g. against the aggression) or natural pressures in order to protect the producer organism. They also give plants their pigment and odors [ $1 \leqslant]$. In our research the antimicrobial activity of Carissa carandas L., Ficus carica L. and Olea europaeae L. leaves were investigated against pathogenic bacterial isolates, beside yeast and fungi.

\section{Materials and Methods}

\section{- Plant Material}

Plants (Carissa carandas L., Ficus carica L. and Olea europaeae L.) were collected from different regions of Baghdad and were classified to their families (Apocyanaceae, Moraceae, Oleaceae) respectively, according to the Department of Biology/Herbal Plants Taxonomy Center for experiments and work.

\section{- Leaves Extracts Preparation}

After the classification step, the plants were washed by tap water then left to dry by air at room temperature for five days. The dried leaves of each plant were transferred to the blender to be grind to its powder. A quantity of $r \circ \mathrm{g}$ of the dried leaves powder was filled in conical flask with r०.ml of $99 \%$ ethanol solvent which had been well mixed and put in Thermo-shaker for $1 \cdots \mathrm{rpm}$ at ${ }^{\mathrm{r}} \cdot{ }^{\circ} \mathrm{C}$ for $V Y$ hrs. The leaves extract was filtered using Whatman No.' filter paper. The leaves extract was centrifuged at $\cdots \cdots$ rpm for $1 \cdot$ minutes. The precipitate was neglected and the supernatant was taken to be concentrated in the oven at $\varepsilon \cdot{ }^{\circ} \mathrm{C}$ for $\varepsilon$ hrs. The dried leaves extract was dissolved in $99 \%$ ethanol to get the stock solution of $r \cdot \mathrm{mg} / \mathrm{ml}[10]$.

\section{Microbial Studies}

\section{- Bacterial Isolates}

Gram negative bacteria isolates (E.coli, $P$. aeruginosa) were identified according to RAPID system Fig.(1), while macroscopic features of Gram positive bacteria (B. subtilus, $S$. aureus) were identified using selective media (MRS agar, Mannitol salt agar) Fig. $(r)$, beside the fungus and yeast (Peniclillium, S.cerevisiae) on Malt agar and Sabouraud agar media Fig. $(\stackrel{\sim}{)}$ then prepared to be tested for the antimicrobial activity of alcoholic leaves extract for Carissa carandas L., Ficus carica L., Olea europaeae L.
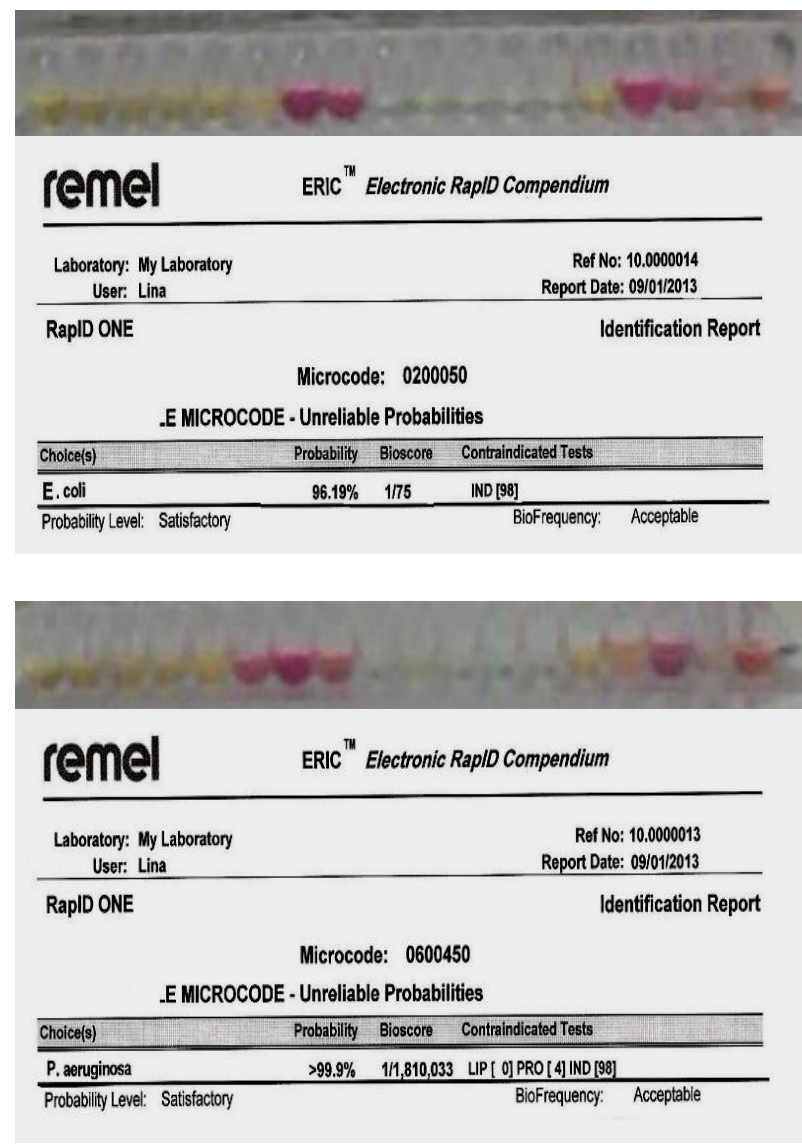

Fig.( ') Identification of Gram Negative bacteria according to ERIC SYSTEM. 


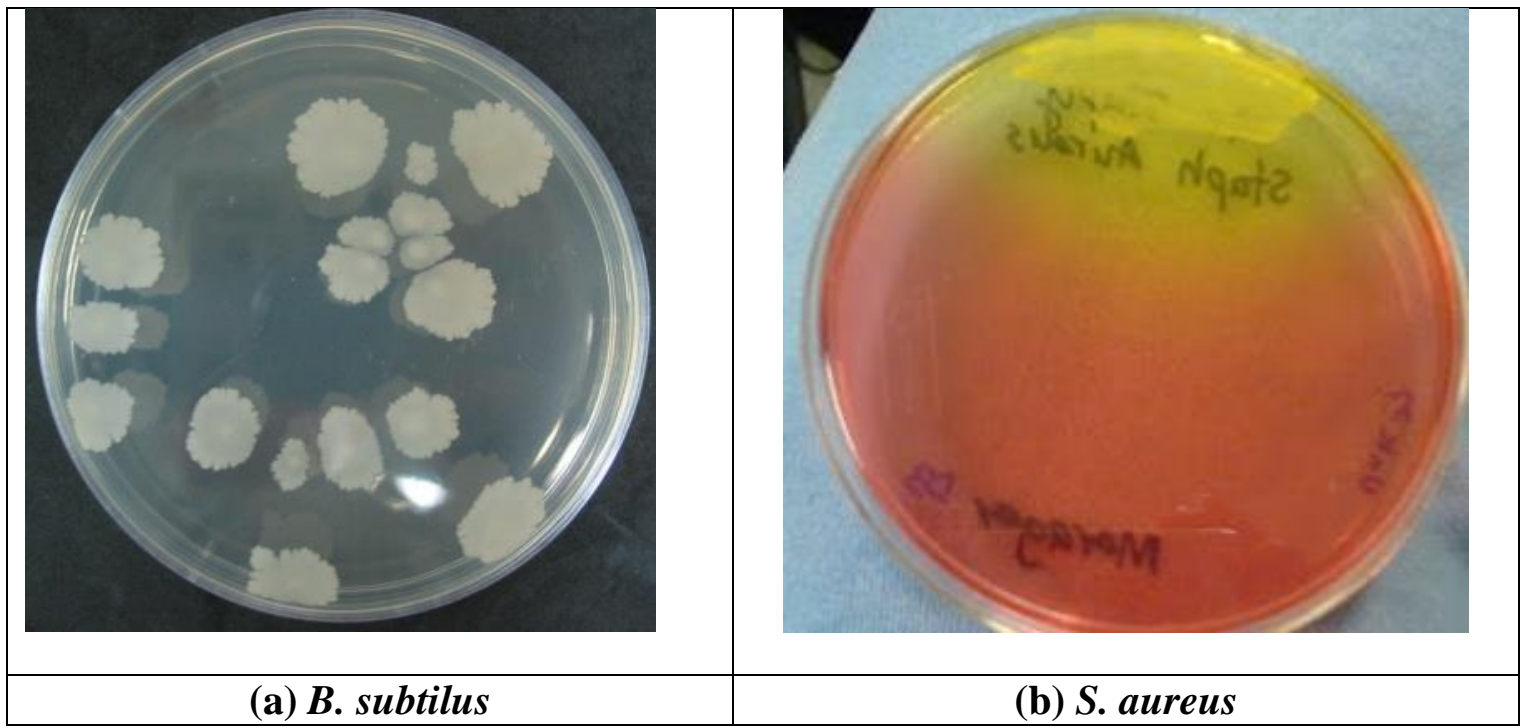

Fig.( (') Identification of Gram Positive bacteria:

(a). B. subtilus on Nutrient Agar. (b) S.aureus on Mannitol Salt Agar.

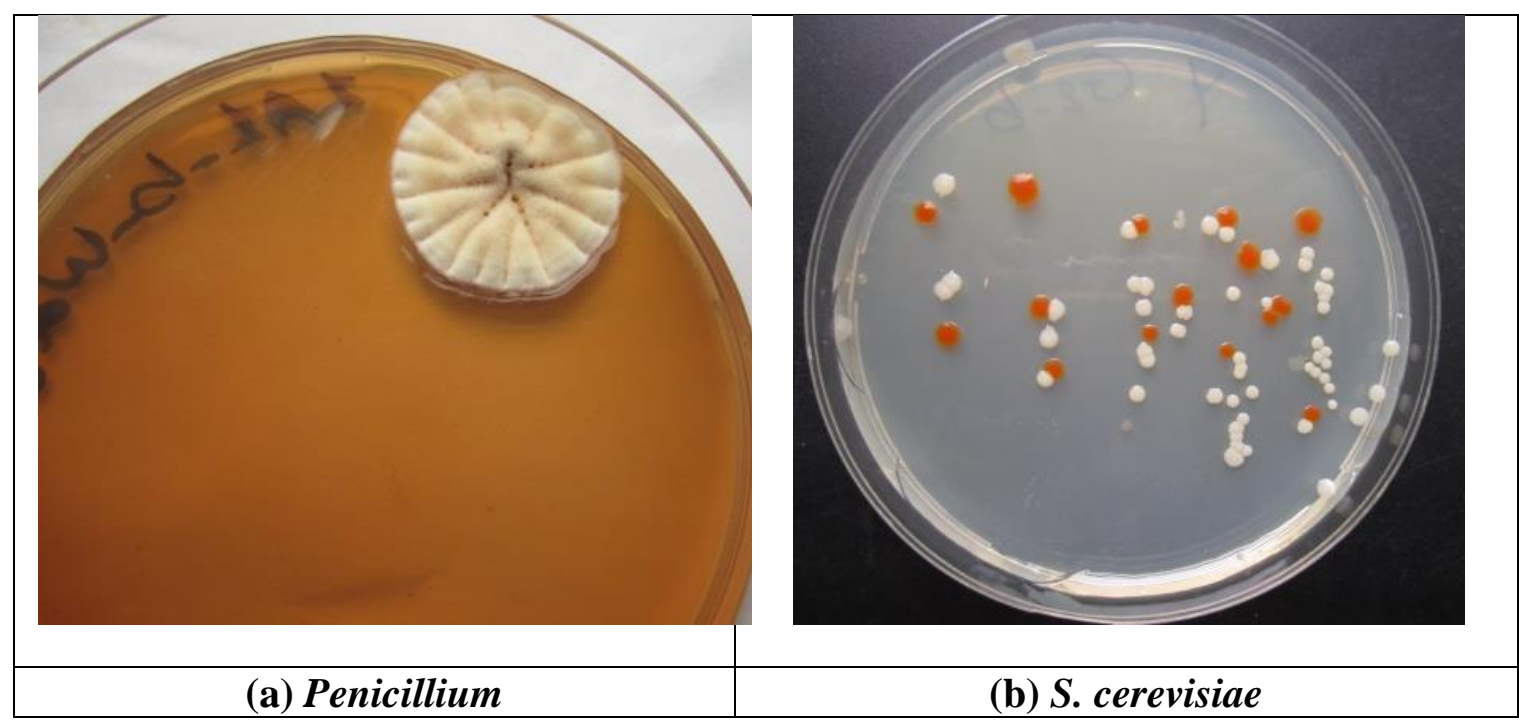

Fig.( ') Identification of Gram Positive bacteria:

(a) Penicillium on Malt Agar. (b) S. cerivisiae on Sabouraud Agar.

\section{- Microbial Activity}

\section{Step I}

Gradient concentrations $(0,1 \cdot, 10$ and $r \cdot \mathrm{mg} / \mathrm{ml}$ ) from alcoholic extract of the plants were prepared individually by diluting the stock solution with ethanol to check the antimicrobial activity.

\section{Step II}

Müller-Hinton Agar plates were prepared according to the manufacturing company, and then poured in the Petri dish. Four wells of $\wedge_{\mathrm{mm}}$ diameter were punched into the agar medium and filled with the gradient concentrations for each plant, while the well made in the center contained the control that considered being absolute ethanol only as shown below:

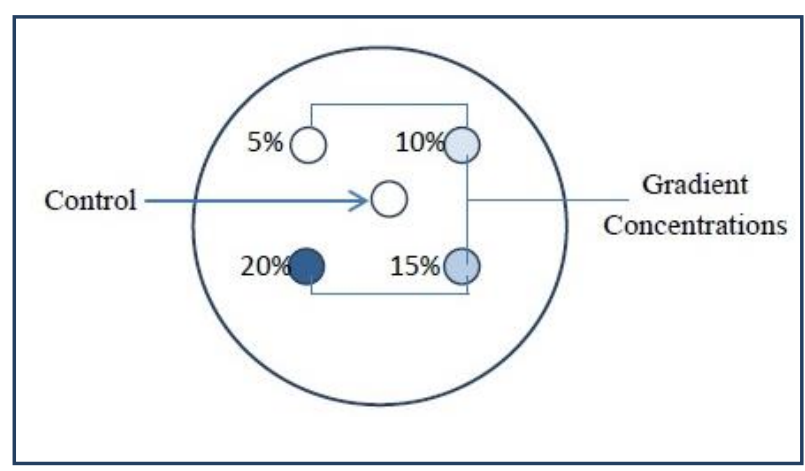




\section{Step III}

The wells method was applied to examine the microbial activity by culturing the isolates on the agar media of thick streaking by sterile swabs. Gradient concentrations were added clockwise with $1 \cdots \mu$ l in each well using sterile micropipette. The plates with the microbial isolates were incubated at ${ }^{\mathrm{r}}{ }^{\circ} \mathrm{C}$ for $r$ shrs., while the yeast and the fungus were incubated at $\mathrm{r}^{\circ} \mathrm{C}$ for $r-\checkmark$ days respectively. Inhibition zones were measured with millimeter and recorded after incubation for further discussion [ [ 17 ].

\section{Results and Discussion}

Carissa carandas L., alcoholic leaves extract showed the highest inhibition zones at the concentration of $r \cdot \mathrm{mg} / \mathrm{ml}$ and $10 \mathrm{mg} / \mathrm{ml}$ and less ability to inhibit the microbial growth in the concentrations of 1 , and $0 \mathrm{mg} / \mathrm{ml}$ (Table (1)) Fig.( ( ).

Gram negative bacteria (E. coli, $P$. aeruginosa) were more sensitive to the crude leaves extract in all studied concentrations, while Gram positive (B. subtilus, S. aureus) beside fungus and yeast ( $S$. cerevisiae, Penicillium) were moderately inhibited Fig. $\left(^{\circ}\right)$. Many studies were conducted to investigate the antimicrobial activity in vitro and in vivo for the leaves, stem and flowers extract of this plant either alcoholic or watery which supported the recorded antimicrobial activity of the crude alcoholic leaves extract for the whole green plant in this study $[1 \mathrm{~V}, 1 \wedge]$.

Table (')

Inhibition zones ( $\mathrm{mm}$ ) caused by the antimicrobial activity of the leaves crude extract concentrations ( $\bullet, 1 \cdot, 10, r \cdot m g / m l)$ for the Carissa carandas $L$.

\begin{tabular}{|c|c|c|c|c|c|}
\hline \multirow[b]{2}{*}{ M.O. } & \multicolumn{5}{|c|}{$\begin{array}{c}\text { Carissa carandas L. leaves extract } \\
\text { concentration }(\mathrm{mg} / \mathrm{ml})\end{array}$} \\
\hline & - & 0 & 1. & 10 & $r$. \\
\hline E.coli & $\cdot \mathbf{m m}$ & $r \cdot \mathbf{m m}$ & $10 \mathrm{~mm}$ & $r \cdot \mathbf{m m}$ & $r \cdot \mathbf{m m}$ \\
\hline P. aeruginosa & $\cdot \mathbf{m m}$ & $r \cdot \mathbf{m m}$ & $1 \cdot \mathbf{m m}$ & romm & romm \\
\hline S. aureus & $\cdot \mathbf{m m}$ & $1 \cdot \mathbf{m m}$ & $1 \cdot \mathbf{m m}$ & romm & romm \\
\hline B. subtilus & $\cdot \mathbf{m m}$ & ${ }^{\circ} \mathbf{m m}$ & $1 \cdot \mathbf{m m}$ & $r \cdot \mathbf{m m}$ & $r \cdot \mathbf{m m}$ \\
\hline S. ceriviseae & $\cdot \mathbf{m m}$ & $10 \mathrm{~mm}$ & $1 \cdot \mathbf{m m}$ & $r \cdot \mathbf{m m}$ & $r \cdot \mathbf{m m}$ \\
\hline Penicillium & · mm & ${ }^{\circ} \mathbf{m m}$ & • $\mathrm{mm}$ & $r \cdot \mathbf{m m}$ & $r \cdot \mathbf{m m}$ \\
\hline
\end{tabular}




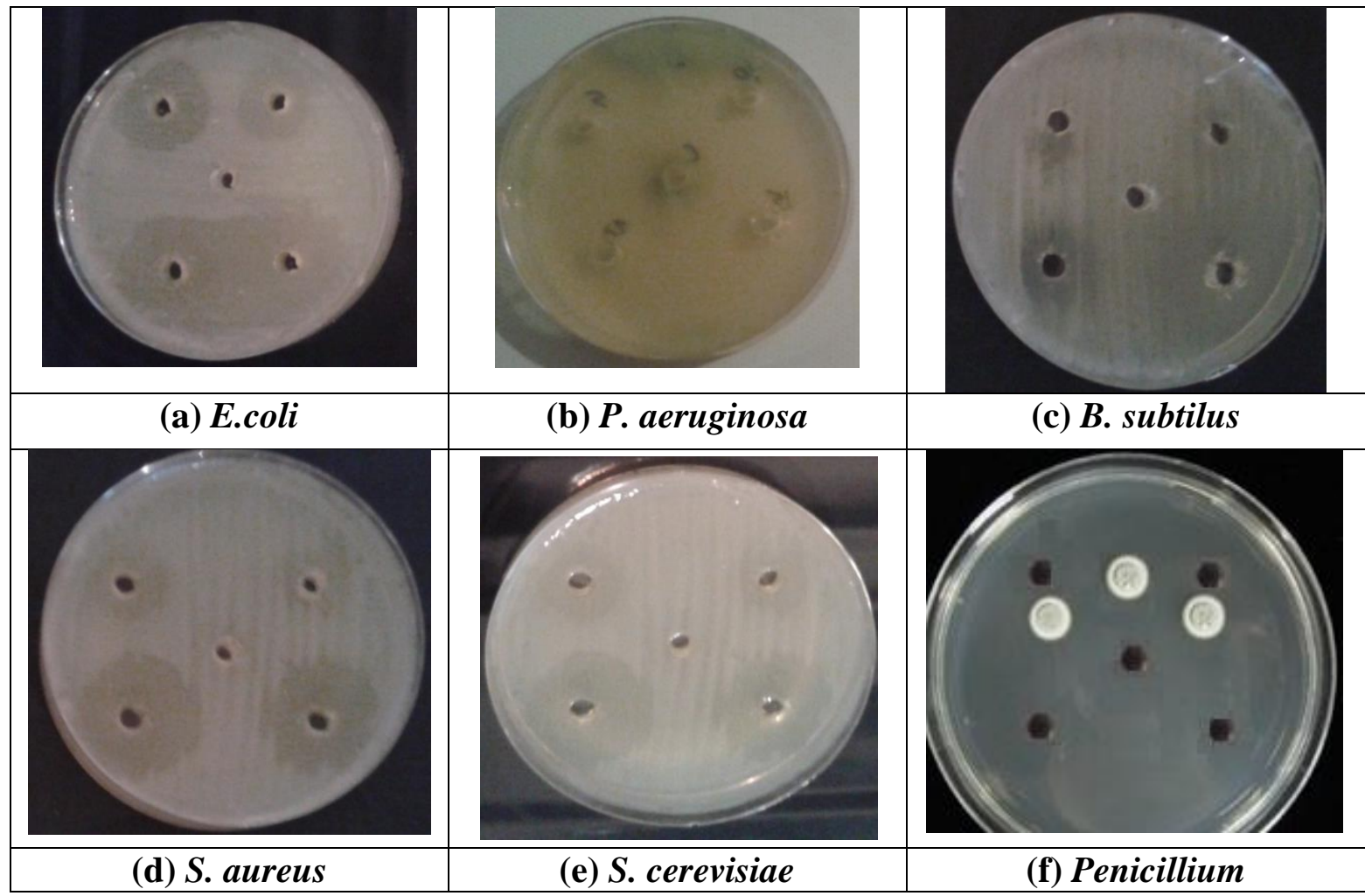

Fig. ( ) The antimicrobial activity of the leaves crude extract concentrations for the Carissa carandas $L$.

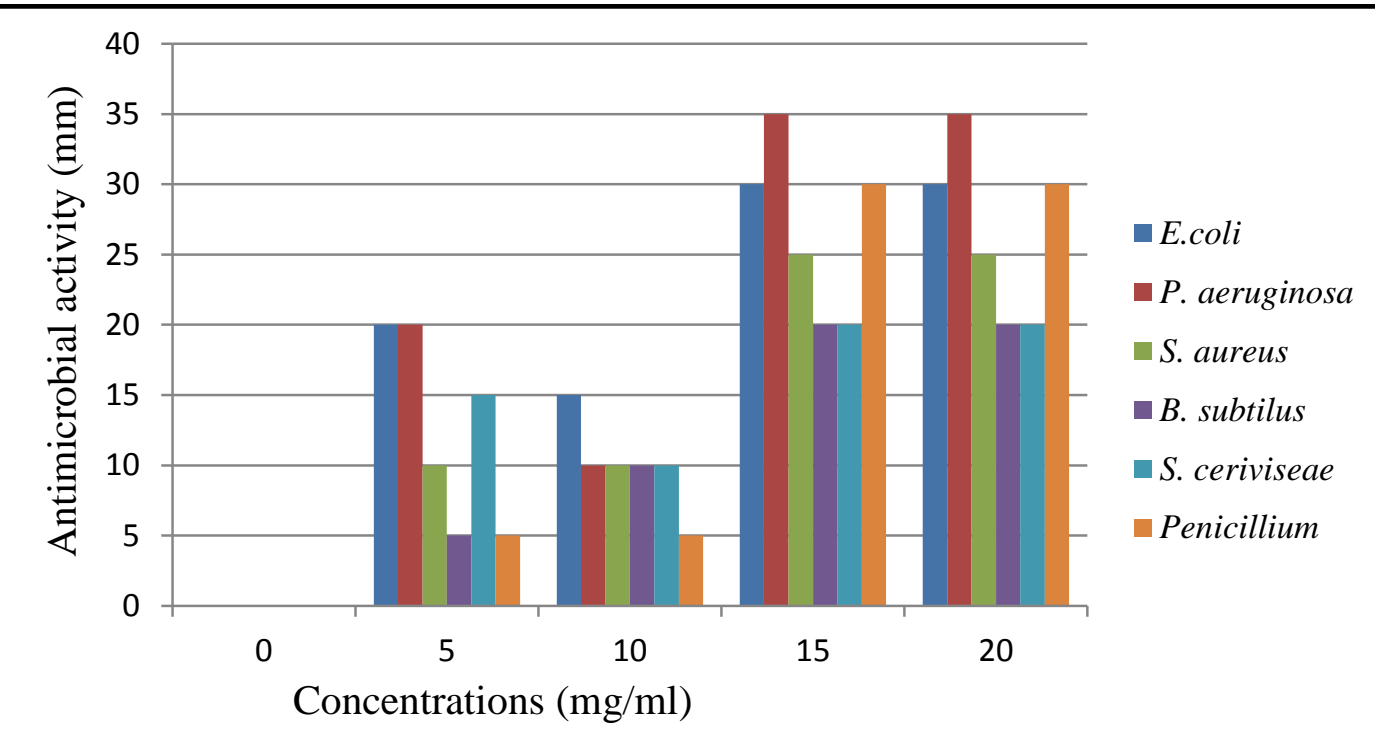

Fig. ( ( ) The antimicrobial activity of the Carissa carandas L. crude leaves extract concentrations against different microbial groups.

The Ficus carica L. alcoholic leaves extract inhibited the microbial growth in all concentrations against the microbial groups that were examined in this paper (Table $(r))$ Fig.( ( $)$. Both Gram negative and positive bacteria were sensitive especially in the high concentrations beside the yeast and fungus Fig. $(\vee)$. This high activity related to the rich content of phenols, essential oils, flavonides and other bioactive compounds such as arabinose, $\beta$-amyrins, $\beta$-carotenes, glycosides, $\beta$-setosterols and xanthotoxol mimicking antibiotics' action in targeting the protein synthesisand the cell wall synthesis $[9,1 \cdot, 1 \wedge]$. 
Table (

Inhibition zones (mm) caused by the antimicrobial activity of the leaves crude extract concentrations $(0,1 \cdot 1,0, r \cdot m g / m l)$ for the Ficus carica $L$.

\begin{tabular}{|c|c|c|c|c|c|c|}
\hline \multirow[b]{2}{*}{ M.O. } & \multicolumn{5}{|c|}{ Ficus carica L.leaves extract concentration $(\mathrm{mg} / \mathrm{ml})$} & \\
\hline & . & 0 & 1. & 10 & $r \cdot$ & \\
\hline E.coli & $\cdot \mathbf{m m}$ & $r \cdot \mathbf{m m}$ & $10 \mathrm{~mm}$ & $r \cdot \mathbf{m m}$ & $r \cdot \mathbf{m m}$ & \multirow{6}{*}{ 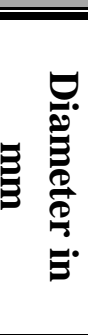 } \\
\hline P. aeruginosa & $\cdot \mathbf{m m}$ & $1 \cdot \mathbf{m m}$ & $r \cdot \mathbf{m m}$ & $r \cdot \mathbf{m m}$ & $r \cdot \mathbf{m m}$ & \\
\hline S. aureus & $\cdot \mathbf{m m}$ & ${ }^{\circ} \mathbf{m m}$ & ${ }^{\circ} \mathbf{m m}$ & $10 \mathrm{~mm}$ & $10 \mathrm{~mm}$ & \\
\hline B. subtilus & $\cdot \mathbf{m m}$ & $10 \mathrm{~mm}$ & $r \cdot \mathbf{m m}$ & $r \cdot \mathbf{m m}$ & $r \cdot \mathbf{m m}$ & \\
\hline S. ceriviseae & $\cdot \mathbf{m m}$ & $r \cdot \mathbf{m m}$ & $r \cdot \mathbf{m m}$ & romm & romm & \\
\hline Penicillium & $\cdot \mathbf{m m}$ & ${ }^{\circ} \mathbf{m m}$ & ${ }^{\circ} \mathbf{m m}$ & $10 \mathrm{~mm}$ & $10 \mathrm{~mm}$ & \\
\hline
\end{tabular}

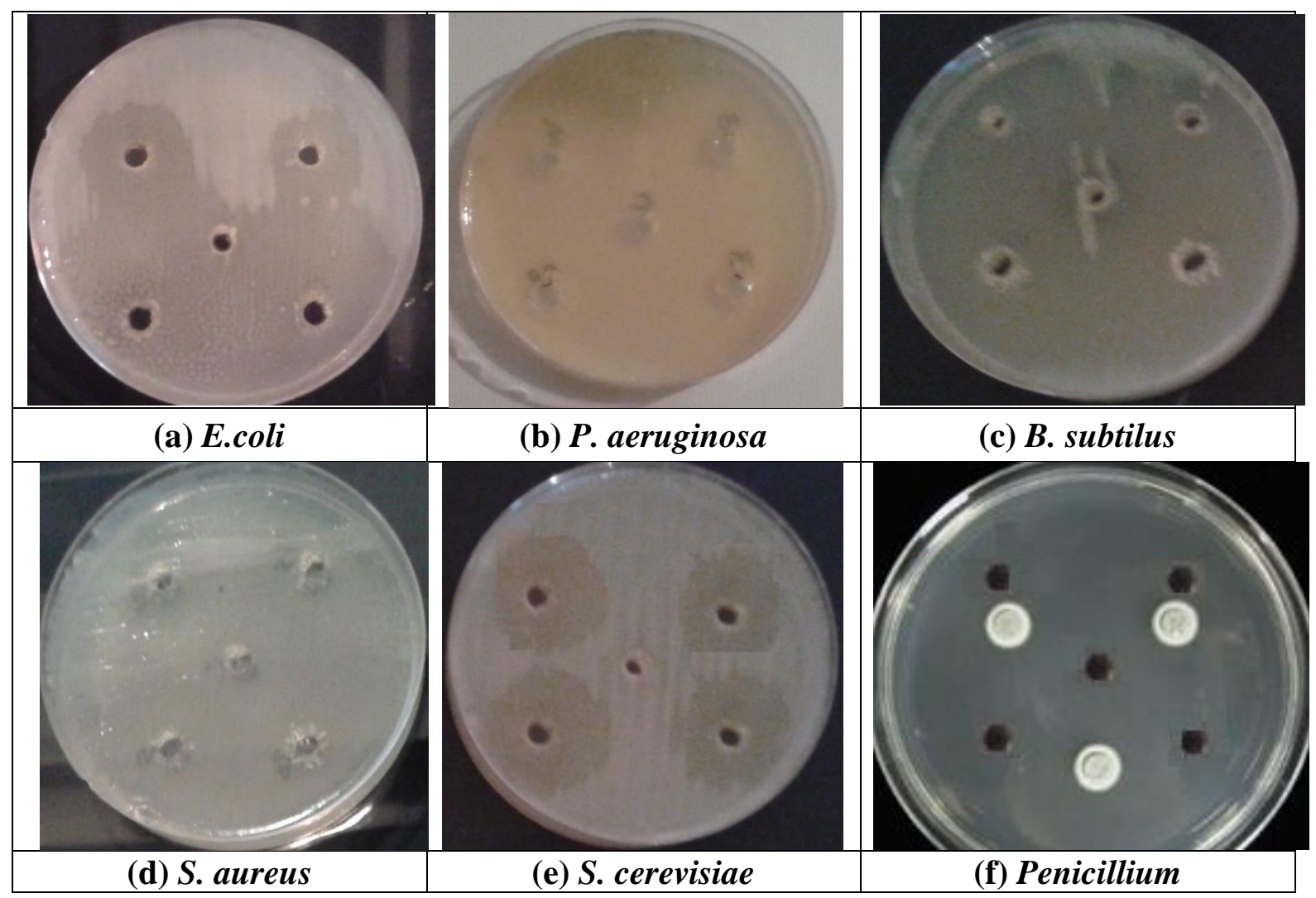

Fig. ( ') The antimicrobial activity of the leaves crude extract concentrations for the Ficus carica $L$. 


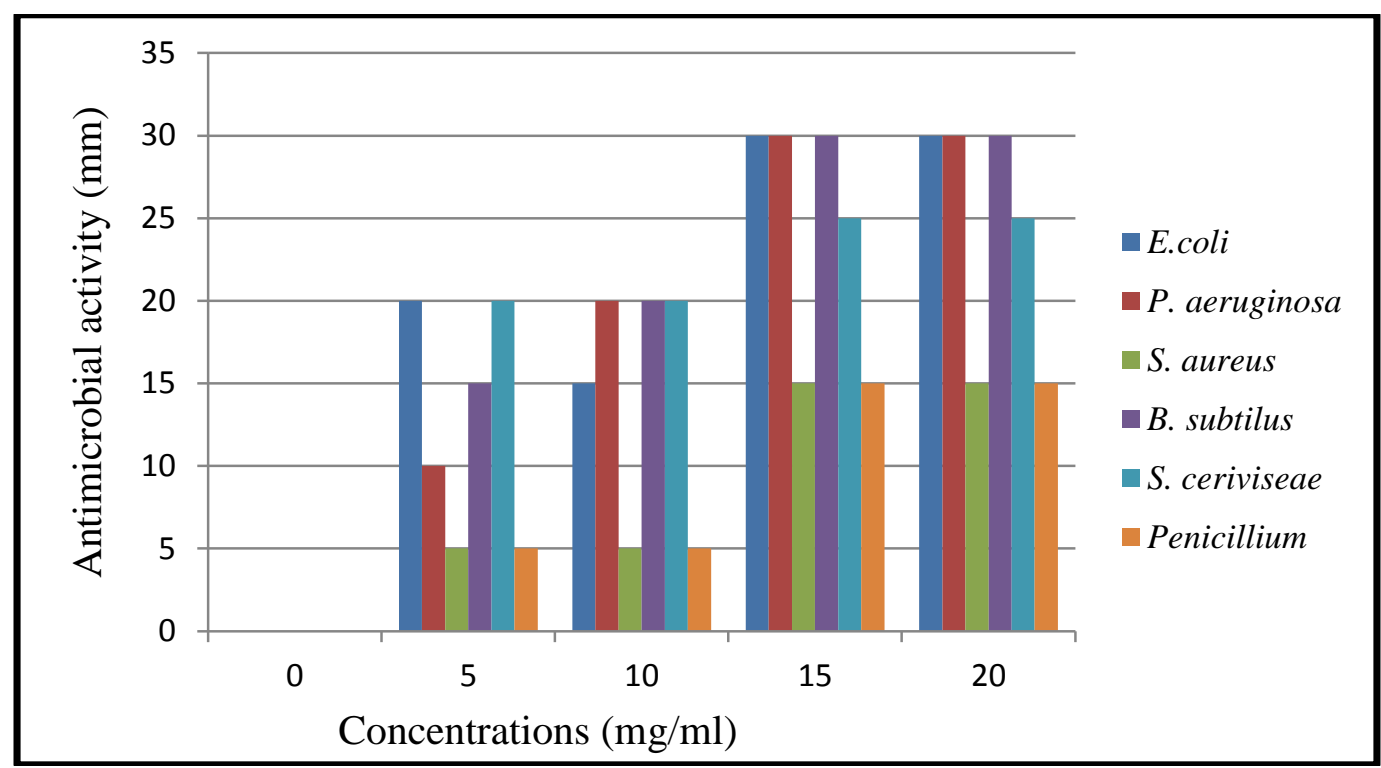

Fig. ( V) The antimicrobial activity of the Ficus carica L. crude leaves extract concentrations against different microbial groups.

Olea europaeae L. alcoholic crude leaves extract were tested against the same microbial groups and showed high activity against both Gram negative bacteria beside $S$. aureus and yeast (Table $(\stackrel{\sim}{)})$ ) Fig. $(\wedge)$ while less inhibition zones were recorded against $B$. subtilus and fungi because of the spore formation ability which protect the microbial cells Fig.( $(9)$. The microbial activity of alcoholic crude extract was doubled according to its content of hydroxytyrosol and its derivatives (e.g. oleuropein complex) which were also reported by other studies $[19, r \cdot, r, r r]$.

Table (')

Inhibition zones ( $\mathrm{mm}$ ) caused by the antimicrobial activity of the leaves crude extract concentrations $(0,1,1,+, r \cdot m g / m l)$ for the Olea europaeae $L$.

\begin{tabular}{|c|c|c|c|c|c|c|}
\hline \multirow[b]{2}{*}{ M.O. } & \multicolumn{5}{|c|}{ Olea europaeae L.leaves extract concentration $(\mathrm{mg} / \mathrm{ml})$} & \\
\hline & . & 0 & 1. & 10 & $r$. & \\
\hline E.coli & $\cdot \mathbf{m m}$ & $1 \cdot \mathbf{m m}$ & $r \cdot \mathbf{m m}$ & romm & $10 \mathrm{~mm}$ & \\
\hline P. aeruginosa & $\cdot \mathbf{m m}$ & $10 \mathrm{~mm}$ & $r \cdot \mathbf{m m}$ & $r \cdot \mathbf{m m}$ & $r \cdot \mathbf{m m}$ & \\
\hline S. aureus & $\cdot \mathbf{m m}$ & $10 \mathrm{~mm}$ & $\boldsymbol{\theta}^{\mathbf{m} m \mathbf{m}}$ & $r \cdot \mathbf{m m}$ & $r \cdot \mathbf{m m}$ & \\
\hline B. subtilus & $\cdot \mathbf{m m}$ & $1 \cdot \mathbf{m m}$ & • $\mathbf{m m}$ & $r \cdot \mathbf{m m}$ & $r \cdot \mathbf{m m}$ & $\frac{2}{2}$ \\
\hline S. ceriviseae & $\cdot \mathbf{m m}$ & $r \cdot \mathbf{m m}$ & $10 \mathrm{~mm}$ & $\mathbf{\theta}^{\mathbf{\theta} \mathrm{mm}}$ & $r \cdot \mathbf{m m}$ & $\overrightarrow{3}$ \\
\hline Penicillium & $\cdot \mathbf{m m}$ & ${ }^{\circ} \mathbf{m m}$ & romm & $\boldsymbol{\theta}_{\mathrm{mm}}$ & $\boldsymbol{\theta}^{\mathrm{emm}}$ & \\
\hline
\end{tabular}




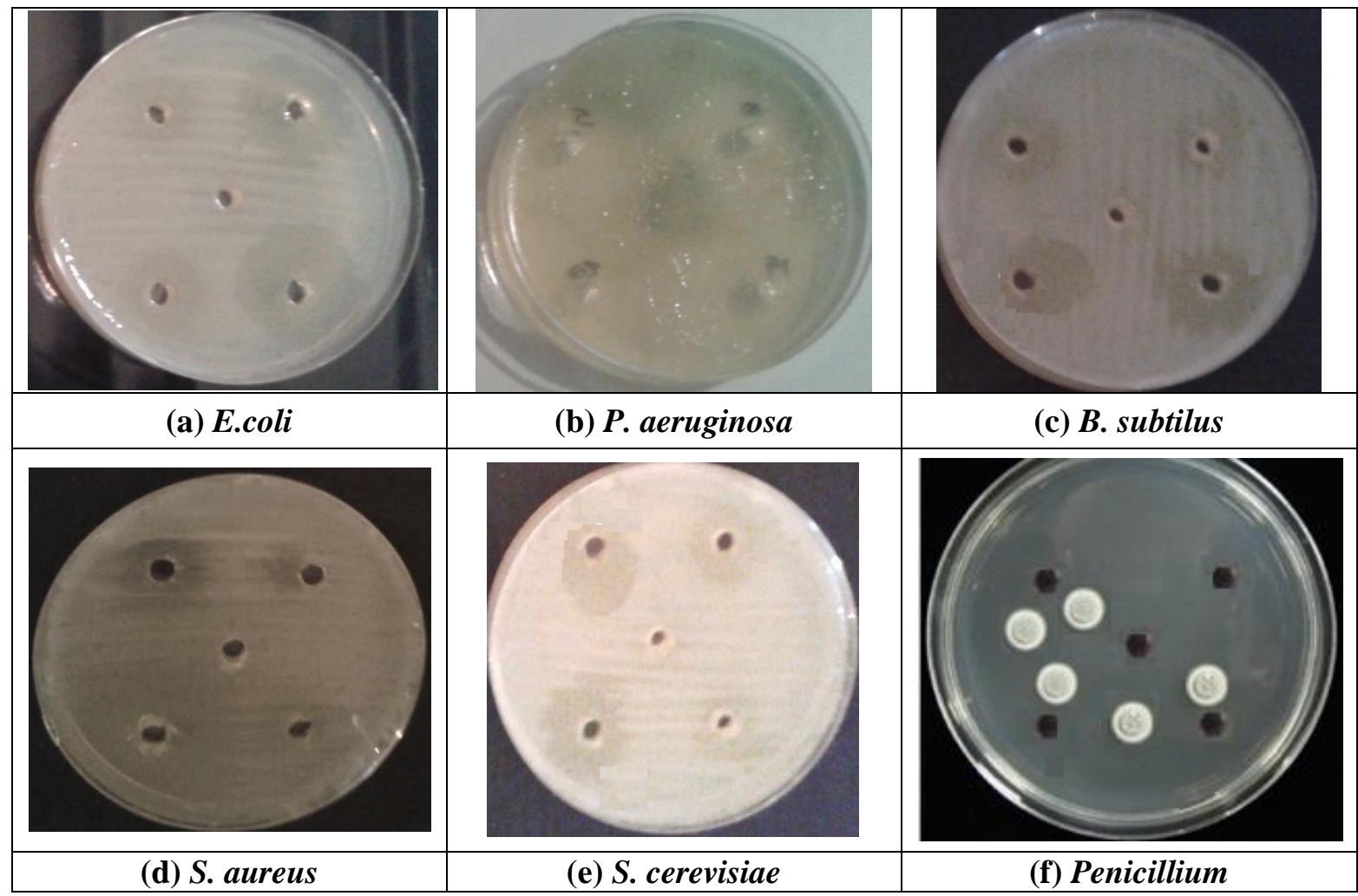

Fig. (1) The antimicrobial activity of the leaves crude extract concentrations for the Olea europaeae $L$.

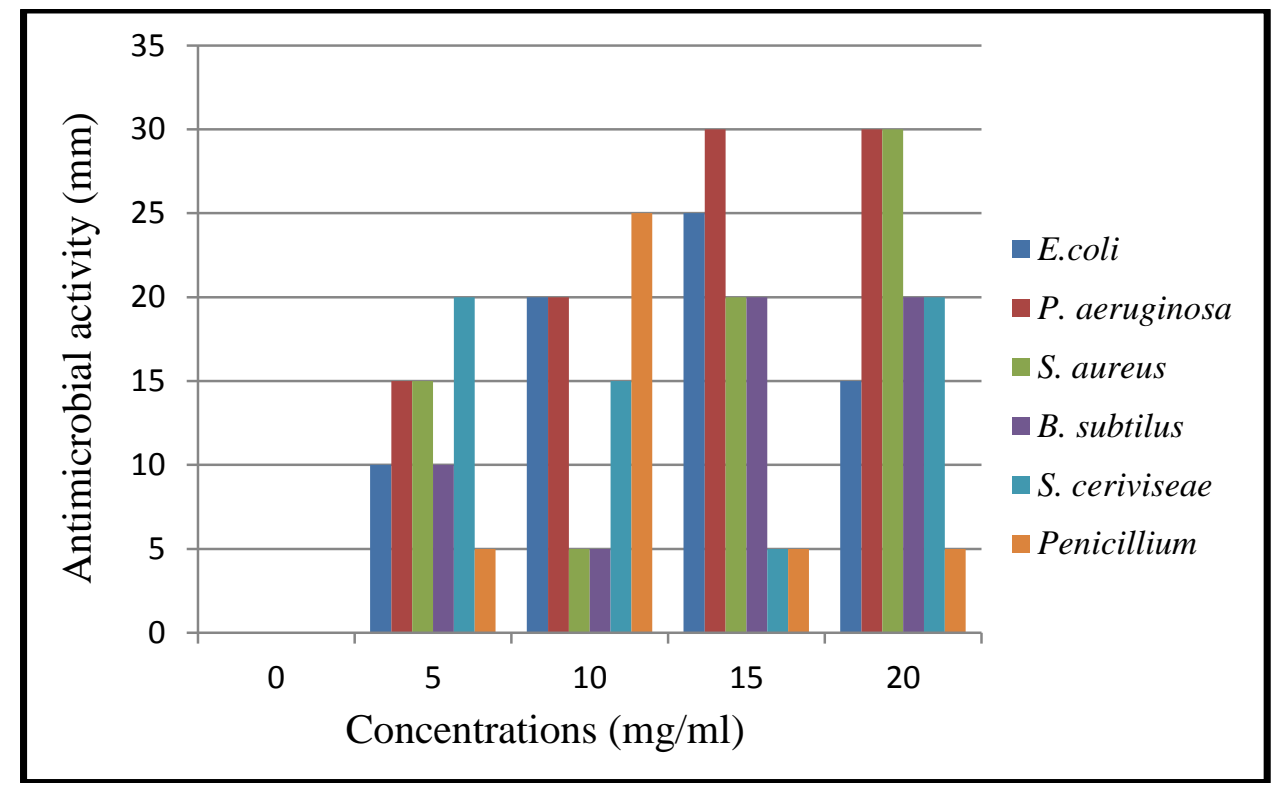

Fig.( (9) The antimicrobial activity of the Olea europaeae L. crude leaves extract concentrations against different microbial groups.

According to the results obtained from this study its clear that the three alcoholic crude leaves extracts inhibited the microbial growth in different ways depending on its bioactive contents besides the minerals and vitamins that can also be found in association with the leaves extract that worked either as one constituent or as a mixture of effective inhibitors. From the results, we can conclude that Ficus carica L. gave the best antimicrobial activity while both Carissa carandas L. and Olea europaeae L. showed higher activity against E.coli, $P$. aeruginosa, $S$. aureusand $S$. cerevisiaeas they had a little effect on B. subtilus, and Penicillium; also gradient concentrations might play a major role in the extract activity Fig. $(1 \cdot)$. 


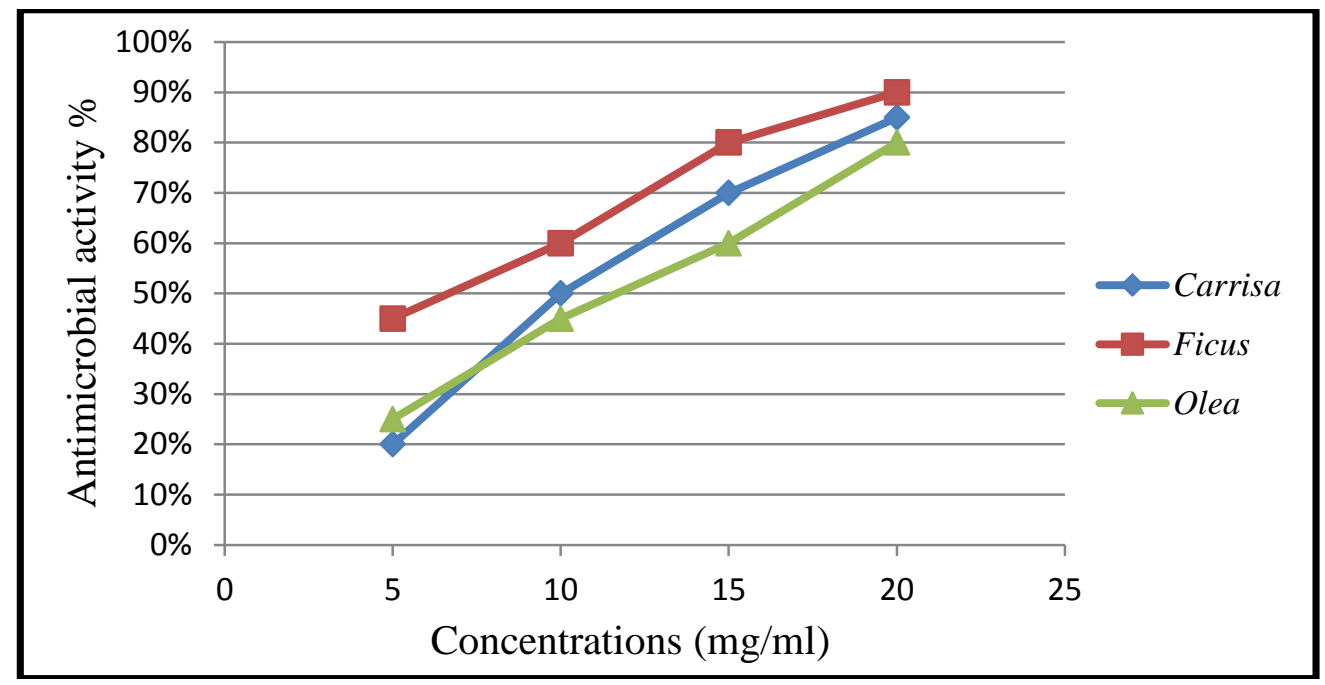

Fig. ( 1 .) The qualification of the antimicrobial activity of the Carissa carandas L., Ficus carica L. and Olea europaeae L. crude leaves extract concentrations against different microbial groups.

The alcoholic leaves extracts showed a significant inhibition against the microbial growth, which is related to their bioactive substances. Both $P$. aeruginosa and S. aureus showed significant results to the alcoholic leaves extracts of Carissa carandas L., Ficus carica L. and Olea europaeae L., while E.coli, B. subtilus, S. cerevisiae, and Penicillium showed non-significant results. Bacterial growth was inhibited by the mode of action of these active mid-products that worked as killing agents at high concentrations. Leaves extracts were approved to heal many diseases even some of them are still awaiting to be discovered and tested $\left[r^{r}, r \varepsilon\right]$.

\section{References}

[1] Gerard, D. and Hendrik, P., "Antibiotic resistance is ancient: implications for drug discovery", Trends in Microbiology, $r \cdot$, $\left.(\varepsilon), 10 V_{-}\right) 109, r+1 r$.

[r] Yun, C.; Dong, C.; Falagas, M.; Vouloumanou, E.; Wang, R.; Guo, D.; Bai, N.; Liang, B. and Youning, L., "Immediate hematological toxicity of linezolid in healthy volunteers with different body weight: a phase I clinical trial", The Journal of Antibiotics, $70,1 Q_{-} \mid \vee \wedge, Y .1 Y$.

[r] Chen, J.; Zhou, X.; Zhang, Y. and Gao, H., "Potential toxicity of sulfanilamide antibiotic: binding of sulfamethazine to human serum albumin", Sci Total Environ, $10, \leqslant r T: Y 79-V \leqslant, Y \cdot 1 r$.

[₹] Maciver, I., "Antibiotics and Honey-An Old Solution for a New Problem", UK Department of Health report, $r \cdot I r$.
[0] Müller, P.; Alber, D.; Turnbull, L.; Schlothauer, R.; Carter, D.; Whitchurch, C. and Harry, E., "Synergism between Medihoney and Rifampicin against Methicillin-Resistant Staphylococcus aureus (MRSA)", PLoS ONE, $\left({ }^{r}\right)$, e 0 VTVq, $r \cdot 1 r$.

[7] Calvo, M.; Arosemena, E.; Shiva, C. and Adelantado, C., "Antimicrobial activity of plant natural extracts and essential oils: by Science against microbial pathogens: communicating current research and technological advances", A. Mendez Vilas (ed.). $\left.11 \vee q_{-}\right) 110, Y \cdot 11$.

$[\vee$ ] Rajasekaran, A. and Murugesan, S., "Antibacterial activity of leaf extracts of Carissa carandas", Humdard Medius, $\_\wedge$, $\left.\Lambda_{-}\right) \cdot$, Y... 0 .

[^] Singh, B. and Sangwan, P., "Toxonomy, ethnobotany and antimicrobial activity of Alstonia scholaris, Carissa carandas and Catharanthus roseus", Int.j.biotech \& BioSci., '( ), $\left.\left.1 \cdot r_{-}\right) 1 r_{,}, r_{-}\right)$.

[9] Kubmarawa, D.; Khan, M.; Punah, A. and Hassan, M., "Phytochemical and antimicrobial screening of Ficus platyphylla against human/animal pathogens", Pac. J. Sci. Technol., ' •, rیr. rAo, r.. 9.

[1.] Aref, H.; Karima, B.; Chaumont, J.; Fekih, A.; Mahjoub, A. and Said, K., "In vitro antimicrobial activity of four Ficus carica latex fractions against resistant human pathogens (antimicrobial activity of Ficus carica latex)", Pak. J. Pharmaceutical Sci., rr, or_on, r.1.

[1)] Oyelana, O.; Durugbo, E.; Olukanni, O. and Ayodele, E., "Antimicrobial activity of 
Ficus leaf extract on some fungal and bacterial pathogens of Dioscorea rotundata from southwest Nigeria". Journal of Biological Sciences, $11(0)$, rоя_rчт, r. Il.

[I $\left.{ }^{Y}\right]$ Khan, Y.; Panchal, S.; Vyas, N.; Butani, A. and Kumar, V., "Olea europaea: A phyto-pharmacological review",

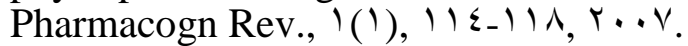

[1T]Daoud, Z.; Abdou, E. and Abdel-Massih, R., "Antimicrobial activity of Rheum Rhaponticum, Olea europaea and Viola odorata on ESBL producing clinical isolates of E.coli and Klebsiella pneumonia", IJPSR, r( $\vee$ ), I $179-17 \vee \wedge$, r. 11 .

[1 $\varepsilon]$ Shnaiwer, N., "Study of some chemical components of Tecoma stans $L$. plant and its extracts effects on some pathogenic bacteria", PhD. Thesis, Department of Biology, College of Science, University of Baghdad, $Y \cdot I r$.

[10] Singh, K.; Tiwari, V. and Prajapat, R., "Study of antimicrobial activity of medicinal plants against various multiple drug resistance pathogens and their molecular characterization and its bioinformatics analysis of the antibiotic gene form genomic database with degenerate primer prediction", International Journal of Biological Technology. I( $(r), 10_{-} 19, r \cdot 1 \cdot$.

[1 7] Agarwal, T.; Singh, R.; Shukla, A. and Waris, I., "In vitro study of antibacterial activity of Carissa carandas leaf extracts", Asian Journal of Plant Science and Research, $r(1), r_{-} \varepsilon \cdot, r \cdot \mid r$.

$[\mathrm{I} V]$ Sundar, A. and Jawahar, M., "Screening of antibacterial activity of leaf and root extracts of Carissa carandas L.-An important traditional medicinal plant", Journal of Agricultural Technology, 9(1), $\left.90_{-}\right) \cdot r, r \cdot 1 r$.

[1^]Adwan, G. and Mhanna, M., "Synergistic effects of plant extracts and antibiotics on Staphylococcus aureus strains isolated from clinical specimens", Middle-East Journal of Scientific Research, $r(r), I r \varepsilon_{-}$ $1 r q, r \cdots \wedge$.

[19] Benavente-García, O.; Castillo, J.; Lorente, J.; Ortuño, A. and Del Rio, J., "Antioxidant activity of phenolics extracted from Olea europaea L. leaves.

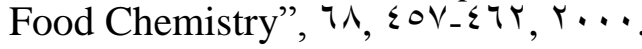

$[r \cdot]$ Bouaziz, M. and Sayadi S., "Isolation and evaluation of antioxidants from leaves of a Tunisian cultivar olive tree", Eur

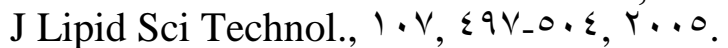

[Y)] Korukluoglu, M.; Sahan, Y.; Yigit, A.; Tumay, O. and Gucer, S., "Antibacterial activity and chemical constitution of Olea europaea L. leaf extract", Journal of food processing and preservation, $r \leqslant(r)$, r $\wedge$ r. rq ,,$\cdot 1$.

$[r\}]$ European Food Safety Authority (EFSA), Parma, Italy, "Scientific Opinion on the substantiation of a health claim related to polyphenols in olive and maintenance of normal blood HDL-cholesterol concentrations" (ID 17rq, further assessment) pursuant to Article $1 \mathrm{r}(1)$ of Regulation (EC) No $19 Y \varepsilon / r \ldots 7)$. EFSA Journal, $1 \cdot(\Lambda), r \wedge \varepsilon \wedge, r \cdot \mid r$.

$\left[{ }^{r}\right]$ Harvey, A., "Strategies for discovering drugs from previously unexplored natural products", Drug Discovery Today, ${ }^{\circ}(\vee)$,

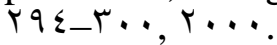

[Y $\left.{ }^{Y}\right]$ Suffredini, J.; Sader, H.; Goncalves, A.; Reis, A.; Gales, A.; Varella, A. and Younes, R., "Screening of antimicrobial extracts from plants native to the Brazilian Amazon rain forest and Atlantic forest", J.

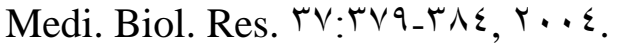

الخلاصة

تستعمل المستخلصات النبانية كعلاج للعديد من

الأمراض، لذلك تم جمع ثناثة نباتات طبية هي: Carissa Olea europaeae L. ‘Ficus carica L.،carandas L. من ضواحي مختلفة من بغداد. حيث اختبرت فعالية

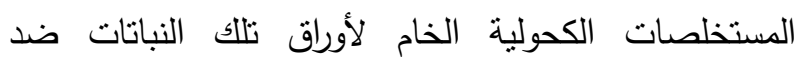

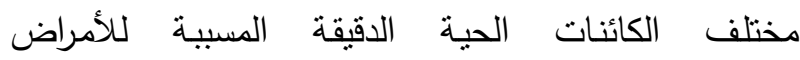
التي شملت: البكتيربا السالبة لصبغة والبكتريا الموجبة لصبغة غرام (E. coli, P. aeruginosa)

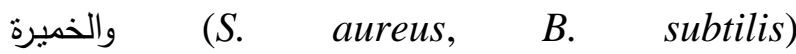
(S. cerevisiae) الاختبارات لمضادات الميكروبات بواسطة طريقة الانتشار بالوسط الصلب (الاكار). أظهرت المستخلصات النباتية للأوراق تأثيرات مختلفة على الكائنات الحية الدقيقة المختلفة

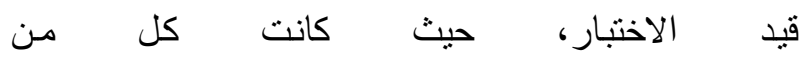

S. cerevisiae،S. aureus ‘P. aeruginosa 6 . coli حساسة للمستخلصات الكحولية للأوراق بينما اظهرت بكتربا Penicillium و B. subtilus

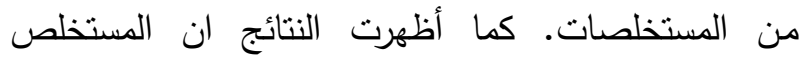
الكحولي لأوراق نبات . Ficus carica L. اعطى تأثنراً أعلى من المستخلصات النباتية الاخرى مقارنة بالمستخلصات

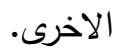


Journal of Al-Nahrain University

Science

Vol. I $\vee(\varepsilon)$, December, $r \cdot 1 \leqslant$, pp. $\mid \leqslant \varepsilon-10 r$ 